\author{
Sławomir Wyciślak \\ Uniwersytet Jagielloński \\ e-mail: slawomir.wycislak@gmail.com
}

\title{
PODEJŚCIE SYSTEMOWE JAKO ŹRÓDLO EFEKTYWNOŚCI W DZIAŁANIACH ORGANIZACJI
}

\begin{abstract}
Streszczenie: Celem artykułu jest wskazanie związków podejścia systemowego i efektywności działań organizacji. Podejście badawcze zastosowane w pracy charakteryzuje ujęcie ontologicznych i epistemologicznych uwarunkowań złożoności, opis rozwoju paradygmatu systemowego, przedstawienie uporządkowanego postępowania służącego opanowaniu złożoności. Do najważniejszych efektów poznawczych artykułu zaliczyć należy ujęcie warunków efektywności działań organizacji przy uwzględnieniu wymogów związanych z istniejącą złożonością. Są to między innymi reguła 20/80, zasada suboptymalizacji, prawo Ashby'ego, zasada preferencyjnego przyłączania węzłów. Najważniejszą zaletą podejścia systemowego jest uwzględnienie dynamiki wynikającej z zachodzących sprzężeń zwrotnych. W ten sposób identyfikuje się źródła efektywności, które uwzględniają całkowity potencjał wykorzystywanych zasobów.
\end{abstract}

Słowa kluczowe: system, efektywność, złożoność, podejście systemowe, organizacja.

DOI: $10.15611 /$ pn.2015.386.24

\section{Wstęp}

Współczesne organizacje funkcjonują $\mathrm{w}$ warunkach rosnącej destabilizacji, która jest pochodną konstytuującej się złożoności. Perspektywą badawczą, która oferuje instrumentarium wymagane do zapewnienia efektywnych działań w warunkach złożoności, jest podejście systemowe. Ruch systemowy może bowiem być interpretowany jako podejmowanie kolejnych prób w celu wyjaśnienia fenomenu złożoności. W konsekwencji wykorzystanie podejścia systemowego może przyczynić się do zwiększenia efektywności działania organizacji. Przyjmując takie założenia, w pierwszej części rozważań skupiono się na opisie wybranych uwarunkowań złożoności przy uwzględnieniu perspektywy badawczej respektującej sferę: epistemologiczną, ontologiczną. W kolejnej części dociekań ujęto opis podejścia systemowego, jego ewolucję i najważniejsze etapy rozwoju. W końcu przedstawiono metodykę postępowania oferowaną $\mathrm{w}$ ramach podejścia systemowego, uwzględniając przy tym reguły mające zastosowanie w działaniu systemów. 


\section{Ontologiczne i epistemologiczne i uwarunkowania złożoności}

Istnieje wiele zapatrywań w zakresie pojmowania istoty złożoności. Odzwierciedla to szereg definicyjnych ujęć wzmiankowanego terminu [Mesjasz 2010]. W kontekście badań nad organizacjami wydaje się, że zasadne jest przyjęcie założenia zarówno o stopniu skomplikowania problemów, jak i kompleksowości. Naturalnie, problemy kompleksowe mogą być skomplikowane. A problemy skomplikowane mogą być kompleksowe. Przy czym może być tak, że problem skomplikowany może nie być kompleksowy. Złożoność jest konsekwencją zjawisk związanych z dynamiką i nieliniowością zachodzącą w organizacji. Oznacza ona nadwrażliwość na warunki początkowe lub ewolucję charakteryzującą się wieloma bifurkacjami (inaczej rozdzieleniami, rozdwojeniami). W konsekwencji, dynamika nieliniowa powoduje, iż przebieg zjawisk staje się nieprzewidywalny. Jest tak dlatego, że może konstytuować się wiele trajektorii i wyłonić się wiele atraktorów [Mesjasz 2010]. Dynamika zjawisk może również charakteryzować się tym, że niewielkie zakłócenia mogą prowadzić do zmian podobnych do lawin (avalanches) o najróżniejszych rozmiarach. Po takich zmianach następuje powrót do stanu z którego implikowany jest kolejny ciąg zdarzeń. Jednocześnie takie zmiany są nieuniknione [Bak 1996]. Dynamika zachodzących zjawisk dotyczy sytuacji, w których przyczyny i skutki są subtelne, a efekty działań w czasie nie są oczywiste. Odnosi się ona również do sytuacji, kiedy to samo działanie daje zasadniczo odmienne efekty w krótkim i długim okresie, kiedy ta sama akcja powoduje pewne konsekwencje lokalne i zupełnie inne konsekwencje w odległej części systemu, kiedy oczywiste działania przynoszą nieoczywiste konsekwencje [Senge 2000].

Przedstawiciele praktyki gospodarczej również podejmują próby identyfikacji typów złożoności, jak i jej konsekwencji. Na przykład, wyróżnia się złożoność, która przekłada się na znaczny wzrost kosztów, a potencjalnie może generować małą wartość (np. planowanie). Złożoność, która powoduje wysokie koszty i daje dużą wartość, np. innowacje produktowe, nowe kanały sprzedaży. Złożoność, która niszczy wartość marki wskutek nadmiernie rozbudowanego portfolio, jak i złożoność, która prowadzi do redukcji kosztów dzięki zmianom dostawców i źródeł zaopatrzenia surowcowego.

W działaniach organizacji konsekwencją złożoności jest brak dopasowania między zakłóceniami wynikającymi ze złożoności, a stosowanymi środkami zaradczymi. Naturalnie, jest to zawsze kwestia subiektywna, zależna od konkretnej organizacji. Konsekwentnie, do rozstrzygnięcia pozostaje, jak doprowadzić do dopasowania stosowanych środków zaradczych do zakłóceń związanych ze złożonością.

W badaniach dotyczących złożoności przyjmuje się perspektywę podejścia systemowego. Przy czym, respektowane są w tym względzie dwa podejścia. Jedno z nich zakłada redukowanie złożoności, a wedle drugiego należy badać rzeczy złożone w ich złożoności. 
Redukcjonizm zakłada, że złożone procesy i teorie z nimi związane można zredukować do bardziej podstawowych, elementarnych zjawisk, ogólnych pojęć teoretycznych. I w ten sposób można wyjaśniać strukturę i funkcjonowanie obiektów złożonych [Richardson 2005]. Oznacza to, że zjawiska wyższego poziomu złożoności thumaczy się za pomocą zjawisk o niższym stopniu złożoności. Natomiast, z punktu widzenia odmiennej perspektywy badawczej podstawowy kanon podejścia systemowego podważa redukcjonistyczno-izolacjonistyczne podejście, a rzeczy złożone należy badać w ich złożoności [Senge 2000].

Niezależnie od przyjętej perspektywy analitycznej wydaje się, że redukcja złożoności jest nieodzowna w działaniach organizacji, a jej przejawem jest identyfikacja systemu. Co więcej, przyjęcie założenia o redukcji złożoności wymuszają ograniczone możliwości poznawcze. Nie oznacza to jednak rezygnacji z badań uwzględniających wieloaspektowe sprzężenia zwrotne zachodzące $w$ ramach badanych zjawisk. Szczególnie uwzględniwszy implikacje prawa Ashby’ego. Mówi ono, że jeśli obniżona zostanie różnorodność aparatu kontrolnego (organizacyjna złożoność) poniżej poziomu wymaganego przez system, nie będzie on w stanie realizować kontroli (czyli nie przetrwa). Tak więc, organizacja typu przedsiębiorstwo powinna działać w ten sposób, aby z jednej strony zwiększać kompleksowość w ramach niektórych działań, a w innych ją redukować. Zwiększający się stopień kompleksowości prowadzi do większego dopasowania działań w warunkach rosnącej złożoności otoczenia. Przedsiębiorstwa, które zredukują kompleksowość działań osiągają krótkookresowy wzrost efektywności oparty na bieżącym dostosowaniu do złożoności panującej w otoczeniu. Jednakże w dłuższym okresie, ze względu na brak długookresowego dopasowania, takie organizacje nie przetrwają.

Ponieważ coraz trudniej jest przewidywać następstwa złożoności, przedsiębiorstwo dostosowuje się do nich, zwiększając elastyczność, i np. produkuje w rytmie zgodnym ze zgłoszonymi zamówieniami, minimalizując czas dostawy, stan zapasów, koszty pracy (umowy „śmieciowe”). Jednocześnie próbuje się redukować złożoność związaną z planowaniem.

Kolejną czynnością jest rozstrzygnięcie, czy pracować w ramach systemu czy nad systemem. Wielu menedżerów pracuje w systemie, a nie nad systemem. W związku z tym nie potrafią myśleć krytycznie i refleksyjnie. Stąd biorą się kryzysy przywództwa, tak jak w przypadku Nokii, Microsoftu czy BlackBerry. Natomiast praca nad systemem sprzyja innowacyjności, kreatywności, wyzwalaniu potencjału, obiektywizacji obserwacji.

\section{O podejściu systemowym}

Dorobek wypracowany w ramach podejścia systemowego może być postrzegany jako podejmowanie kolejnych prób w celu wyjaśniania fenomenu złożoności [Wyciślak 2013]. Stosownie do tego wyróżnia się pierwszą falę teorii systemowych, niedługo po II wojnie światowej, związaną zastosowaniem urządzeń wykorzystujących 
sprzężenie zwrotne, a także rozwojem komputerów; drugą falę związaną z osiągnięciami cybernetyki i dynamiki systemów oraz trzecią falę, bazującą na nowym pojmowaniu równowagi w ramach teorii dyskontynuacyjnych [Anderson 1999].

Tabela 1. Nurty podejścia systemowego

\begin{tabular}{|l|l|l|}
\hline \multicolumn{1}{|c|}{$\begin{array}{c}\text { Nurt podejścia } \\
\text { systemowego }\end{array}$} & \multicolumn{1}{|c|}{ Przedmiot badań } & \multicolumn{1}{|c|}{ Przedstawiciele } \\
\hline $\begin{array}{l}\text { Ogólna teoria } \\
\text { systemów }\end{array}$ & $\begin{array}{l}\text { hierarchia, celowościowość, różnorodność, } \\
\text { morfogeneza, stabilność, ultrastabilność, } \\
\text { emergencja i ewolucja, entropia, wejścia - } \\
\text { wyjścia, ekwifinalność }\end{array}$ & $\begin{array}{l}\text { Von Bertalanffy, Gerard, } \\
\text { Rapoport, Boulding, Klir, Simon } \\
\text { Pichler, Miller, Mesarovic } \\
\text { i Takahara }\end{array}$ \\
\hline Cybernetyka & $\begin{array}{l}\text { sterowanie, informacja, komunikacja, } \\
\text { autonomia, współzależność, kooperacja, } \\
\text { konflikt, autopojeza, samoorganizacja, } \\
\text { samokontrola, samoodniesienie, } \\
\text { samotransformacja, złożone systemy } \\
\text { dynamiczne }\end{array}$ & $\begin{array}{l}\text { Wiener, Ashby, Pask, Von } \\
\text { Foerster, Zopf, Beer, McCulloch }\end{array}$ \\
\hline $\begin{array}{l}\text { Systemy } \\
\text { dynamiczne }\end{array}$ & $\begin{array}{l}\text { symulacja interakcji, sprzężenia zwrotne, rola } \\
\text { opóźnien, zapasy i przepływy }\end{array}$ & Forrester, Meadows, Richardson \\
\hline $\begin{array}{l}\text { Teorie dynamiki } \\
\text { nieliniowej }\end{array}$ & bifurkacje, atraktory, chaos, porządek & Mandelbrot, Prigogine \\
\hline $\begin{array}{l}\text { Metodologia } \\
\text { systemów }\end{array}$ & $\begin{array}{l}\text { ogólna interwencja systemowa, integracyjna } \\
\text { metodologia systemowa }\end{array}$ & $\begin{array}{l}\text { Churchman, Vester, Checkland, } \\
\text { Ulrich, Jackson, Schwaninger, } \\
\text { Gharajedaghi }\end{array}$ \\
\hline
\end{tabular}

Źródło: opracowanie własne na podstawie [Schwaninger 2006; François 1999; Laszlo, Krippner 1998].

Ogólna teoria systemów, cybernetyka, teoria chaosu i teoria katastrof są ukierunkowane na wyjaśnianie zachowania systemów deterministycznych. Natomiast inny jest model wyjaśniania w ramach adaptacyjnych systemów złożonych. Cechą tego kierunku badawczego jest to, że wyłaniający się porządek jest efektem interakcji zachodzących na niższych poziomach zagregowania [Anderson 1999]. Adaptacyjne systemy złożone mają zdolność oddziaływania na swoje otoczenie i zmiany swej struktury bez udziału czynnika zewnętrznego.

Do teorii złożoności zalicza się teorię chaosu, struktur dyssypatywnych oraz złożonych systemów adaptacyjnych. Teoria chaosu i teoria struktur dyssypatywnych są skupione na budowie modeli na ogólnym poziomie, natomiast teoria adaptacyjnych systemów złożonych zakłada podejście wieloagentowe [Burnes 2004].

Podejście systemowe nie może być postrzegane w kategoriach osiągnięć dokonanych w połowie lat 50 . XX wieku, jak to bywa niekiedy czynione. Nauka o systemach ewoluuje, a jej dorobek epistemologiczny i ontologiczny pozwala na lepsze zrozumienie fenomenu złożoności. Podejście systemów i nauka o złożoności powinny być postrzegane wspólnie jako wysiłki mające na celu poznawanie złożoności. 
Jest tak, tym bardziej że zrozumienie osiągnięć podejścia systemowego pozwala na lepszą percepcję obecnego stanu pojmowania złożoności.

Niezależnie od kierunku badań realizowanego w ramach podejścia systemowego, wydaje się, że jego zastosowanie może być źródłem efektywności w działaniach organizacji dzięki zastosowaniu adekwatnej metodyki postępowania i reguł, które opisują działanie systemu. Naturalnie, w takiej interpretacji przyjmuje się, iż organizacja jest systemem.

\section{Metodyka postępowania w warunkach złożoności}

Czynnością, która respektuje wymogi związane z dopasowaniem środków zaradczych do zakłóceń związanych ze złożonością, jest określenie celu. Należy przyjąć, że kreowanie konsumenta, jak i zaspokajanie jego potrzeb jest wiodącym celem przedsiębiorstwa. Tylko pozornie wzmiankowane założenie jest oczywiste, ponieważ korporacje transnarodowe, największe przedsiębiorstwa świata, działają zgodnie z modelem zarządzania wartością dla akcjonariuszy. Tymczasem wartość dla akcjonariuszy powinna być rezultatem zaspokajania potrzeb konsumentów, a nie celem samym w sobie. Ustanowienie celów na zewnątrz przedsiębiorstwa prowadzi do zwiększenia elastyczności. Cele skierowane do wewnątrz dotyczą w dużej mierze wyższej kadry kierowniczej (top management). Niejednokrotnie w większym stopniu skupia się ona na realizacji własnych celów w ramach obszaru funkcjonalnego, a nie na celach przedsiębiorstwa. Bywa również tak, iż przedstawiciele wyższej kadry kierowniczej przekładają efektowną prezentację za pośrednictwem środków multimedialnych nad rzeczową analizę. Bierze się to z pozorowania działań, maskowania intencji i autopromocji. Taka postawa jest pochodną dążenia do uzyskania wysokiej krótkookresowej oceny (np. półrocznej, rocznej). W konsekwencji, w dłuższym okresie, następuje utrwalenie inercji, dochodzi do wypalenia zawodowego, narasta skłonność do manipulacji, jak również przedkładane są kwestie pozamerytoryczne nad dyskusjami merytorycznymi. Efektem takiej sytuacji jest zniechęcenie, frustracja, pogłębiające się podziały, izolacja, a w rezultacie zakłócenia w pracy, dysfunkcje i patologie.

Przykładem próby reorientacji na cele zorientowane na zewnątrz jest podejście firmy Unilever. Implikacje kryzysu 2008+ doprowadziły do zmiany orientacji z krótkookresowej na perspektywę długookresową. Paul Polman, który został prezesem Unilever w 2009 roku, wytyczył długoterminowy cel: podwoić wartość przychodów, zmniejszając jednocześnie o połowę negatywny wpływ na otoczenie w okresie do 2020 roku. Oznacza to aktywne oddziaływanie na otoczenie przedsiębiorstwa w sferach społecznej, ekonomicznej, jak i środowiskowej. W sferze społecznej i ekonomicznej realizowane są działania umożliwiające budowę potencjału rozwojowego (np. akcje edukacyjne). W sferze środowiskowej, podejmowane są próby działań mających na celu redukcję emisji dwutlenku węgla. Realizacja celów na zewnątrz przekłada się na osiągnięcie długookresowej efektywności organizacji. 
Dzieje się tak dzięki rozciągniętemu w czasie wykorzystaniu zasobów i ograniczaniu marnotrawstwa.

Po ustaleniu celu kolejnym etapem postępowania należy uczynić identyfikację granic systemu. W warunkach zintegrowanych działań i współpracy w ramach supply chain granice między przedsiębiorstwami zamazują się, a działania przenikają. Co więcej, przyjmując, że cele przedsiębiorstwa powinny być zorientowane na zewnątrz, zakres zewnętrznego oddziaływania przedsiębiorstwa zwiększa się. Jeśli przedsiębiorstwo jest rozumiane jako system działań, to wtedy granicą jest różnica złożoności między systemem a otoczeniem. Przy czym tworzyć granice oznacza ukonstytuować różnicę w tym sensie, iż stosunki wewnętrzne stają się mniej złożone od zewnętrznych [Steinmann, Schreyögg 1998]. Różnica złożoności nie może być traktowana jako stała, lecz jako parametr. Ponieważ granice są samodzielnie konstytuowane, zatem system ma możliwości ich modyfikacji. Wytyczanie granic jest przez to powtarzalną i wzmagającą się funkcją systemu. Jest tak dlatego, iż systemy posiadają zdolność do uczenia się. W ten sposób następuje rozwój przedsiębiorstwa rozumianego jako system działania [Steinmann, Schreyögg 1998]. Zasięg granic przedsiębiorstwa ulega zatem zmianie wraz z rozwojem organizacji. Przy czym ma to następować przy zachowaniu kryterium długookresowej efektywności.

Kolejną czynnością jest ustalenie wejść i wyjść z systemu. W ramach działań współczesnego przedsiębiorstwa, na wejściach znajdują się wielkości charakteryzujące się rosnącą zmiennością. Zmienność cen jest kompensowana poprzez centralizację zakupów i zawieranie długoterminowych kontraktów. Naturalnie, na wzmiankowane działania mogą sobie pozwolić duże przedsiębiorstwa, wykorzystujące efekt skali. Natomiast na wyjściach otrzymujemy produkty o skracającym się okresie przydatności do spożycia. Wynika to z konfliktu celów, jaki zachodzi między zaspokajaniem potrzeb konsumentów a wzrostem wartości dla akcjonariuszy. Realizacja celu polegającego na maksymalizacji wartości dla akcjonariuszy oznacza preferowanie krótkookresowej perspektywy kwartalnej, półrocznej, rocznej, bo w takim rytmie raportowane są wyniki spółek akcyjnych.

Następnym etapem działań jest określenie relacji między elementami systemu. W tym względzie zastosowanie znajduje reguła 20/80 (zasada Pareto). Mówi ona, że $20 \%$ wysiłków daje $80 \%$ efektów. Naturalnie, istnieją odchylenia od tej zasady, polegające np. na tym, że 16\% nakładów daje 77\% efektów (zgubiono 7\%). Jednakże, jej istota zostaje zachowana. Konsekwencje dla organizacji są takie, że ma następować ciągła koncentracja działań na zasobach, które generują największy efekt. Można by zadać pytanie, dlaczego dochodzi do powstawania tak nierównomiernej relacji nakładów i efektów? Wynika to z nierównomiernego rozłożenia potencjału poszczególnych zasobów. Co więcej, ciągle pojawiają się takie zasoby, które dają w efekcie zasadę 20/80. W konsekwencji w sposób permanentny pojawiają się nowe źródła procesu doskonalenia. Tak więc nieustannie pojawia się potencjał do wzrostu efektywności. 
Zasada suboptymalizacji oznacza natomiast, że gdy poszczególne podsystemy optymalizują swoje działania, to jako całość organizacja (system) działa nieoptymalnie. Bierze się to ze sprzężeń zwrotnych zachodzących między poszczególnymi podsystemami i niejednokrotnie odrębnych celów realizowanych w ich ramach. Konflikty występujące w obrębie organizacji obserwowane są np. w relacjach logistyka - sprzedaż. Na przykład, w praktyce gospodarczej zdarzają się sytuacje, że po 27. dniu miesiąca realizowane jest nawet $25-30 \%$ całej sprzedaży miesięcznej. Dla logistyki szczyty sprzedażowe pod koniec miesiąca przekładają się na konieczność zamawiania zwiększonej liczby ciężarówek i zapewnienie większej powierzchni magazynowej. Inne konsekwencje to opóźnienia dostaw, uszkodzenia i braki towaru, dezorganizacja pracy w magazynach, zatrudnianie pracowników tymczasowych, wyższe wynagrodzenia dla dostawców usług transportowych. Co więcej, w perspektywie całego supply chain oznacza to zwiększenie stanu zapasów. Szczyty sprzedażowe wynikają m.in. ze sposobu motywowania handlowców. Otrzymują oni premię za realizację celów dotyczących wartości sprzedaży w okresach miesięcznych. Skutkuje to skokowym zwiększeniem aktywności pod koniec miesiąca i wzrostem sprzedaży. Wiedząc o tym, partnerzy handlowi (np. sieci handlowe) oczekują, że pod koniec miesiąca otrzymają upusty cenowe. Dlatego wstrzymują się z zamówieniami i realizują je, gdy uzyskają rabaty. Powstaje zatem pętla sprzężenia zwrotnego, którą przerwać może jedynie redefiniowanie celów (istotną przyczyną jest to, że większość pracowników otrzymuje wynagrodzenie pod koniec miesiąca i wtedy robi większe zakupy).

Kolejną czynnością jest opis funkcji systemu. Przy czym funkcje powinny przekładać się na sprawną realizację procesów, włączając w to działania w ramach supply chain. Tymczasem sferami funkcjonalnymi (obecnie niejednokrotnie nazywanymi centrami doskonałości) zarządzają nienaruszalni „,baronowie”, którzy pilnie strzegą granic swoich terytoriów. Dzieje się tak, ponieważ sfery funkcjonalne utrwalają strukturę o charakterze hierarchicznym. Naturalnie, przyczyną tego jest model budżetowania, w ramach którego kontroli poddawane jest zużycie zasobów. Takie podejście jest skorelowane z założeniem, iż głównym celem organizacji ma być kontrola zużycia zasobów. Tymczasem w warunkach konieczności reagowania na zmienne otoczenie nieodzowne są działania o charakterze międzyfunkcjonalnym. W tym względzie podejmowane są próby polegające np. na tworzeniu międzyfunkcjonalnych zespołów, które mają odpowiadać za realizację zleceń pochodzących od partnerów handlowych. Noszą one nazwę zespołów do spraw realizacji zamówień (order full filment group). Ideą takich zespołów jest to, aby zamiast analizować każdą część procesu realizacji zamówienia odrębnie, cały proces i ludzi go obsługujących gromadzi się w jednym miejscu (open space). W praktyce, takie procesy (albo przynajmniej ich część) są realizowane w ramach tzw. centrów kontroli (control towers), w których pracują specjaliści zajmujący się np. planowaniem transportu, fakturowaniem, odzyskiwaniem należności, kontrolą jakości. Centra kontroli tworzone są zgodnie z kryterium regionalnym, np. dla obszaru Europy, Azji, Ameryki 
Południowej [Christopher 2011]. Centra te można traktować jak huby w sieci. Ich konstytuowanie w ramach sieci odpowiada zasadzie preferencyjnego przyłączania węzłów. Oznacza ona, że lepiej usieciowione (mające więcej połączeń) węzły sieci przyciągają nowe połączenia (użytkowników). Zgodnie z tym, centra generują coraz większą liczbę połączeń. W konsekwencji, powstaje w nich coraz więcej miejsc pracy. Przy czym likwidowane są jednocześnie stanowiska pracy w oddziałach korporacji zlokalizowanych w poszczególnych krajach.

Kontrola jest realizowana poprzez mechanizm sprzężeń zwrotnych. W tym względzie zastosowanie znajduje prawo Ashby'ego. Można go interpretować w ten sposób, że aparat kontrolny ma charakteryzować się większą różnorodnością niż ilość stanów, które mają podlegać kontroli. Zapewnienie wysokiej różnorodności znajduje się w pozornej sprzeczności z warunkiem efektywności. Jednak to właśnie różnorodność sprzyja kreatywności i w konsekwencji innowacyjności. Zachodzi więc nieadekwatność skutku do zaistniałej przyczyny. Stąd bierze się też efekt synergii, podstawowe źródło efektywności działań w organizacji.

W praktyce informacja przekazywana w ramach sprzężeń zwrotnych zależy od motywacji i intencji pracowników (ukryte i jawne treści), sposobu komunikowania się (pisemny, ustny, elektroniczny), języka komunikacji (ojczysty, obcy), emocji (pozytywne, negatywne). Czas, w jakim informacja jest przekazywana $\mathrm{w}$ ramach sprzężeń zwrotnych, zależy w największym stopniu od inercji.

$\mathrm{Na}$ wyjściach z systemu otrzymujemy efekty o charakterze intencjonalnym i nieintencjonalnym. Do intencjonalnych efektów zalicza się produkty, usługi zgodne z wyznaczonymi celami. Natomiast wśród efektów nieintencjonalnych wyróżnia się usterki, braki, uszkodzenia, opóźnienia. Stosunek wielkości na wejściach i na wyjściach stanowi o krótkookresowej i długookresowej efektywności działań organizacji.

\section{Zakończenie}

W artykule ujęto wybrane uwarunkowania złożoności, podejścia do redukowania złożoności uwzględniające zarówno redukcję złożoności do prostych reguł, jak i badanie rzeczy złożonych $\mathrm{w}$ ich złożoności. W dalszym ciągu rozważań zaprezentowano rozwój podejścia systemowego, podkreślając, że cały ruch systemowy może być interpretowany jako podejmowanie kolejnych prób w celu wyjaśnienia fenomenu złożoności. Stąd zastosowanie podejścia systemowego może przyczynić się do zwiększenia efektywności działania organizacji. W tym celu zastosowanie znajduje reguła 20/80, zasada suboptymalizacji, prawo Ashby'ego czy też zasada preferencyjnego przyłączania węzłów. Zaletą podejścia systemowego jest identyfikacja źródeł efektywności, uwzględniająca całkowity potencjał wykorzystywanych zasobów. 


\section{Literatura}

Anderson P., 1999, Complexity Theory and Organization Science, Organization Science, vol. 10, no. 3, Special Issue: Application of Complexity Theory to Organization Science.

Bak P., 1996, How nature Works: the science of self-organized criticality, Copernicus, New York.

Burnes B., 2004, Kurt Lewin and complexity theories: back to the future?, Journal of Change Management, vol. 4 , no. 4.

Christopher M., 2011, Logistics and Supply Chain Management, Pearson Education Limited, Harlow, England.

François Ch., 1999, Systemics and Cybernetics in a Historical Perspective, Systems Research and Behavioral Science, vol. 16.

Laszlo A., Krippner S., 1998, Systems Theories: Their Origins, Foundations, and Development, [w:] Systems Theories and A Priori Aspects of Perception, red. J.S. Jordan, Elsevier Science, Amsterdam.

Mesjasz C., 2010, Complexity of Social Systems, Acta Physica Polonica A., vol. 117.

Richardson K.A., 2005, Systems theory and complexity, Part 3 E: CO Issue, vol. 7, no. 2.

Schwaninger M., 2006, System Dynamics and the Evolution of the Systems Movement, Systems Research and Behavioral Science, vol. 23.

Senge M.P., 2000, Piąta dyscyplina. Teoria i praktyka organizacji uczacych się, Dom Wydawniczy ABC, Warszawa.

Steinmann H., Schreyögg G., 1998, Zarządzanie. Podstawy kierowania przedsiębiorstwem. Koncepcje, funkcje, przykłady, Politechnika Wrocławska, Wrocław.

Wyciślak S., 2013, Efekt zarażania a działalność organizacji, Wydawnictwo Uniwersytetu Jagiellońskiego, Kraków.

\section{THE SYSTEM APPROACH AS THE SOURCE OF EFFICIENCY IN ORGANIZATION ACTIVITIES}

Summary: The goal of the article is to describe a system approach as a tool dedicated to complexity mastering. Epistemological and ontological aspects of complexity, the system approach development and the proceedings for dealing with complexity are components of the paper. The most important effects of the article is the identificaton of conditions of efficiency within complexity. These include the 20/80 rule, the principle of suboptimization, the Ashby law and the principle of preferential attachment of nodes. The most important advantage of the system approach is covering the dynamics resulting from the casual loops. The latter opens the way to the identificaton of the efficiency sources including the full potential of the resources used.

Keywords: system, efficiency, complexity, system approach, organization. 